\title{
Geographic variation of skull traits in the Libyan jird, Meriones libycus (Rodentia: Gerbillinae), over its entire distribution area
}

\author{
Igor Ya. Pavlinov, Andrey A. Lissovsky \& Ekaterina V. Obolenskaya
}

ABSTRACT. Geographic variation of 11 measurable cranial traits was studied on a set of 37 local samples of the Libyan jird, Meriones libycus, over its entire distribution area. MANOVA, cluster, canonical discriminant, and regression analyses were applied to consider both scalar and vector parameters of variation. It is shown that the Libyan jird is divided craniometrically into tree principal clusters, African, SW-N Caspian, and "main Asian" ones, which differ basically by auditory bulla size (the least in SW-N Caspian cluster) and incisive foramen length (the least in some subsamples of "main Asian" cluster). Auditory bulla size is shown to be negatively, though not very strongly, correlated with the aridity index. However, the SW-N Caspian cluster is characterized by much smaller bulla than it is predicted by the regression with climatic parameter. This might be explained by some historical causes according to which a small size of auditory bulla in the jirds of that cluster reflects retention of the ancestral condition. It is suggested that subspecies $M$. l. caucasius from Azerbaijan is most conspicuously differentiated by cranial morphology, but its taxonomic relation to M. l. eversmanni from N Caspian region needs further clarification. The method of "vector" analysis of geographic trends within large portions of the areas of widely distributed species, such as M. libycus, seems to be useful in providing additional important information concerning biological specificity of respective territorial groupings.

KEY WORDS: Libyan jird, Meriones libycus, geographic variation.

Igor Ya. Pavlinov [igor_pavlinov@zmmu.msu.ru], Zoological Museum of Moscow State University, Bolshaya Nikitskaya ul. 6, Moscow 125009, Russia; Andrey A. Lissovsky [andlis@zmmu.msu.ru], Zoological Museum of Moscow State University, Bolshaya Nikitskaya ul. 6, Moscow 125009, Russia; Ekaterina V. Obolenskaya [obolenskaya@zmmu.msu.ru], Zoological Museum of Moscow State University, Bolshaya Nikitskaya ul. 6, Moscow 125009, Russia.

\section{Географическая изменчивость признаков черепа краснохвостой песчанки, Meriones libycus (Rodentia: Gerbillinae) на всей территории ареала}

\section{И.Я. Павлинов, А.А. Лисовский, Е.В. Оболенская}

\begin{abstract}
РЕЗЮМЕ. Исследована географическая изменчивость 11 мерных признаков черепа краснохвостой песчанки Meriones libycus на совокупности 37 локальных выборок со всей территории ареала вида. Использованы методы дисперсионного, кластерного, дискриминантного и регрессионного анализа, рассмотрены скалярные и векторные характеристики изменчивости. Показано, что краснохвостая песчанка по краниометрическим показателям чётко делится на три группы - африканскую, прикаспийскую (Ю3 и С Прикаспий) и «основную азиатскую». Они различаются главным образом размерами слухового барабана (наименьшие в прикаспийской группе) и зарезцовых отверстий (наименьшие в некоторых выборках «основной азиатской» группы). Показано, что размеры слухового барабана связаны отрицательной корреляций (впрочем, не очень чётко выраженной) с индексом аридности. Однако песчанки из прикаспийской группы характеризуются существенно меньшими барабанами, чем это предсказано регрессией. Для объяснения этой особенности предполагается, что в названной группе сохранены примитивные особенности слуховой системы. Делается вывод, что закавказский подвид M. l. caucasius наиболее чётко очерчен краниологически, но его связи с северо-каспийской формой M. l. eversmanni требуют уточнения. Использованный метод «векторного» анализа географической изменчивости может быть полезен при изучении пространственной дифференциации видов с широкими ареалами, вроде краснохвостой песчанки, позволяя выявлять биологические особенности внутривидовых региональных группировок.
\end{abstract}

КЛЮЧЕВЫЕ СЛОВА: краснохвостая песчанка, Meriones libycus, географическая изменчивость. 


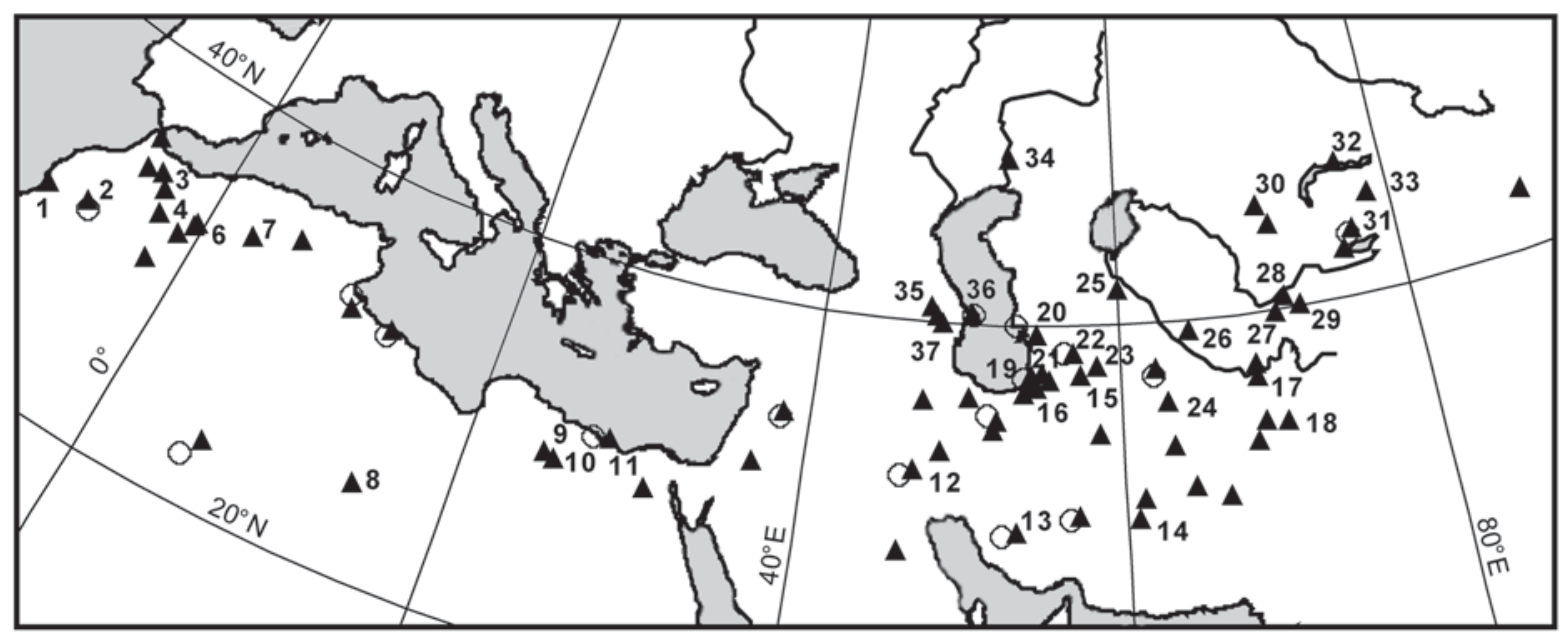

Figure 1. Sampling localities of Meriones libycus used in the main analyses. See text for subsample identification. Geographical positions of weather station, data from which was used in analysis, are shown by hollow circles.

\section{Introduction}

The Libyan jird, Meriones libycus Lichtenstein, 1823 , is one of the most widely distributed species among wild rodents, with its range being extended over nearly entire Palaearctic Desert Belt from Morocco in NW Africa to Xinjiang in C Asia. Its regional differentiation has been described in terms of subspecies taxonomy in several faunal check-lists (Ellermann \& Morrison- Scott, 1951; Gromov et al., 1961; Setzer, 1961; Ranck, 1968), and peculiar pattern of auditory bulla size variation was also revealed at the regional level, as well (Lay, 1967; Pavlinov, 1979). However no overall trends of geographic variation for this species have been traced so far over its entire distribution range. Meanwhile, analysis of these trends in case of cranial traits is of importance, as it allows considering some questions of limits of stability and variability of certain form-functional complexes (in sense of Bock \& Wahlert, 1965) at the species level.

In the present contribution, we consider geographic variation of measurable cranial traits of the Libyan jird characterizing its general skull size and proportions, with special attention being paid to the auditory bulla. Analyses of both global trends and local differentiation are conducted employing several both routine and new numerical methods. Conspecifity of all African and Asian populations and taxonomic nomenclature of the Libyan jird were adopted after the senior author (Pavlinov, 1982; Pavlinov et al., 1990).

\section{Material and methods}

The general sample studied includes 304 specimens of the Libyan jird. The most part of this sample was divided into 37 local subsamples with no less than 3 specimens each (Fig. 1), which were used in the main analysis. This subsamples are as following (figures in brackets indicate specimen numbers): MOROCCO: 1 Agadir (4), 2 - Ouarzazate (15), 3 - Fes (7), 4 Ksar (3); ALGERIA: 5 - Beni Abbes (6), 6 - Ain Sefra (8), 7 - Laghouat (3); LIBYA: 8 - Fezzan (7), 9 - Cyrenaica (3); EGYPT: 10 - Siwa (4), 11 Matruh (13); IRAQ: 12 - Ali Gharb (5); I RAN: 13 Fars (5), 14 - Baluchistan (3), 15 - Bodjnour (3), 16 - Gorgan (4); AFGHANISTAN: $17-$ Kunduz (8), 18 - Jalal Abad (6); TURKMENISTAN: 19 Gassan Kuli (3), 20 - Nebit Dagh (4), 21 - Kyzil Atrek (6), 22 - Kara-Kala (9), 23 - Ashgabat (8), 24 - Takhta Bazar (11), 25 - Tashauz (17); UZBEKISTAN: 26 - Bukhara (6), 27 - Kokand (4), 28 Namangan (4); KYRGYZSTAN: 29 - Osh (10); KAZAKHSTAN: 30 - Betpak Dala (6), 31 - Almaty (8), 32 - N shore of Balkhash Lake (4), 33 - Taldy Kurgan (3), 34 - Emba River (3); AZERBAIJAN: 35 Adjinour (9), 36 - Apsheron (11), 37 - Mil'skaya Steppe (15). Besides, some specimens not included in the above subsamples but used in several analyses, came from the following localities: CHINA: Xinjiang, Turfan (2); SAUDI ARABIA: Qaisumah (2); SYRIA: Palmyra (2); JORDAN: Azrag-Shishan (3).

The material studied herewith is deposited in the collections of the following institutions: Zoological Museum of Moscow Lomonosov University; Zoological Institute of RAS, St. Petersburg; Museum National d'Histoire Naturelle, Paris; American Museum of Natural History, New York; Carnegie Museum of Natural History, Pittsburgh; Field Museum of Natural History, Chicago; National Museum of Natural History, Washington (D.C.).

The skull was described, for the purposes of the present study, by the following measurable traits: 1 . Occipito-nasal length (ONL), 2. Length of nasal bones (NL), 3. Combined width of nasal bones (NW), 4. Minimal interorbital width (IOW), 5. Maximal zygo- 
matic width (ZW), 6. Braincase width at the level of most extended auditory tube anterior to auditory meatus (BCW-1), 7. Braincase width at the level of posterior ream of auditory meatus (BCW-2), 8. Diastema length (DL), 9. Incisive foramina length (IFL), 10. Maximal upper tooth row length (TRL), 11. Maximal bullar length (BL). In additional, relative bullar length (RBL) was calculated as BL/ONL. All subsequent analyses were performed on logarithmic values of original measurements.

Gender allocation of the specimens was taken from museum labels. The skulls with fully erupted molars were included in the sample studied; their relative age was detected by dental morphology using standard method (Pavlinov, 1979). The sex differences were evaluated numerically in 14 samples with $n>6$ and with approximately equal ratio of males and females. Age differences were evaluated numerically between two principal age categories in 6 samples for which sufficient amount of skulls was available. In both cases, the differences between sex and age groups were evaluated separately using two-factor hierarchical MANOVA, in which geographic locality and sex/age groupings were used as factors, with sex/age factors being nested in the geographic one.

In order to exclude effect of sex differences from morphometric analysis, we used an orthogonal projection of initial data along the vector of sex variation (Burnaby, 1966). This vector was calculated as the first eigenvector of the between-group covariance matrix computed with MANOVA, in which sex allocation was used as a grouping variable.

Geographic variation of craniometric traits was evaluated using the following methods.

Hierarchical cluster analysis was performed on the basis of the matrix of Mahalanobis distances between the above 37 local subsamples using UPGMA algorithm. The bias induced by using samples of different sizes was corrected according to (Marcus, 1993).

Ordination of the local subsamples was performed using canonical discriminant analysis. The subsamples with more than 5 specimens each were included in the learning sample in the primary analysis and allocation of other specimens was estimated in the secondary analysis on the basis of their canonical scores.

The "vector" analysis (in sense of Lissovsky \& Pavlinov, 2008; Pavlinov, 2008) was performed to study geographic trends in craniometric variation, for which first eigenvector of the between-group covariance matrix was computed with MANOVA. Two analyses were conducted: a) within each of 3 principal clusters identified by the above analyses, sample name being used as a grouping variable; b) between these clusters on pairwise basis, cluster ID being used as a grouping variable. Resampling procedure was employed to evaluate significance of the differences in geographic trends both between and within clusters, 100 bootstrap replicas of initial data were performed with preservation of withinsample data structure (Lissovsky \& Pavlinov, 2008). Absolute values of vector coordinates were used in all comparisons; principal component analysis of these values was conducted to visualize the differences of interest.

For analysis of the supposed environmental effect on the auditory bulla size, we used De Martonne's aridity index calculated as $\mathrm{AI}=\mathrm{R} /(\mathrm{T}+10)$, where $\mathrm{R}$ is the mean annual precipitation in $\mathrm{cm}$ and $\mathrm{T}$ is the mean annual temperature in ${ }^{\circ} \mathrm{C}$. The initial climatic data used for the calculations were taken from meteorological stations most close to respective sample localities for the period 1961 to 1991 , these data were borrowed from the site http://www7.ncdc.noaa.gov/CDO/georegion, using choice Monthly Global. The only exclusion was Azerbaijan for which no total monthly precipitation could be found; for this, mean annual precipitation was borrowed from another source (Afonin et al., 2006), its value corresponding to the range indicated in (Borisov, 1977).

All analyses were made using standard modules of STATISTICA 8.0 (StatSoft, 2007) and several custom algorithms written by the second author using Statistica Visual Basic programming language.

\section{Results}

Preliminary analyses. Age differences in the skull traits were first evaluated. No statistically significant differences were revealed in the subsamples studied (Wilks' lambda $=0.019, \mathrm{p}=0.065$ ), so the subsequent analyses were conducted on the materials with no age segregation. Sex differences appeared to be statistically significant, though not very high (Wilks' lambda = $0.170, p=0.023)$. The effect of the latter differences on geographic comparisons was eliminated by the above Burnaby transformations of original data.

Analysis of geographic grouping. Hierarchical cluster analysis of the differences between local subsamples indicates their clear differentiation into three main regional groups (Fig. 2). One of them, most separated, includes four samples from SW (Azerbaijan) and N (Emba River) of Caspian region. Another one includes most of other Asian subsamples from Iran, Afghanistan, Turkmenistan, Uzbekistan, and Kazakhstan, while the third one includes all African subsamples from Morocco to Egypt added with several those from Iran. The pairwise comparison of the subsamples indicates the following: the Mahalanobis distance values within the SW-N Caspian cluster is equal to 3.50-13.31, within the "main Asian" cluster is equal to $1.12-17.70$, within the African cluster is equal to $0.00-18.10$. The distances between three main clusters are 5.70-99.41, the African and "main Asian" clusters being most similar.

More detailed pattern of geographic differentiation is uncovered by canonical discriminant analysis. The 1 st canonical variable takes about 67 per sent of total variance, it is correlated mostly with BL (-0.54) and BCW-2 (-0.34). The $2 \mathrm{~d}$ canonical variable takes only about 10 per sent of total variance, it is correlated mostly with IFL (-0.57) and also with BCW-2 (-0.36). 


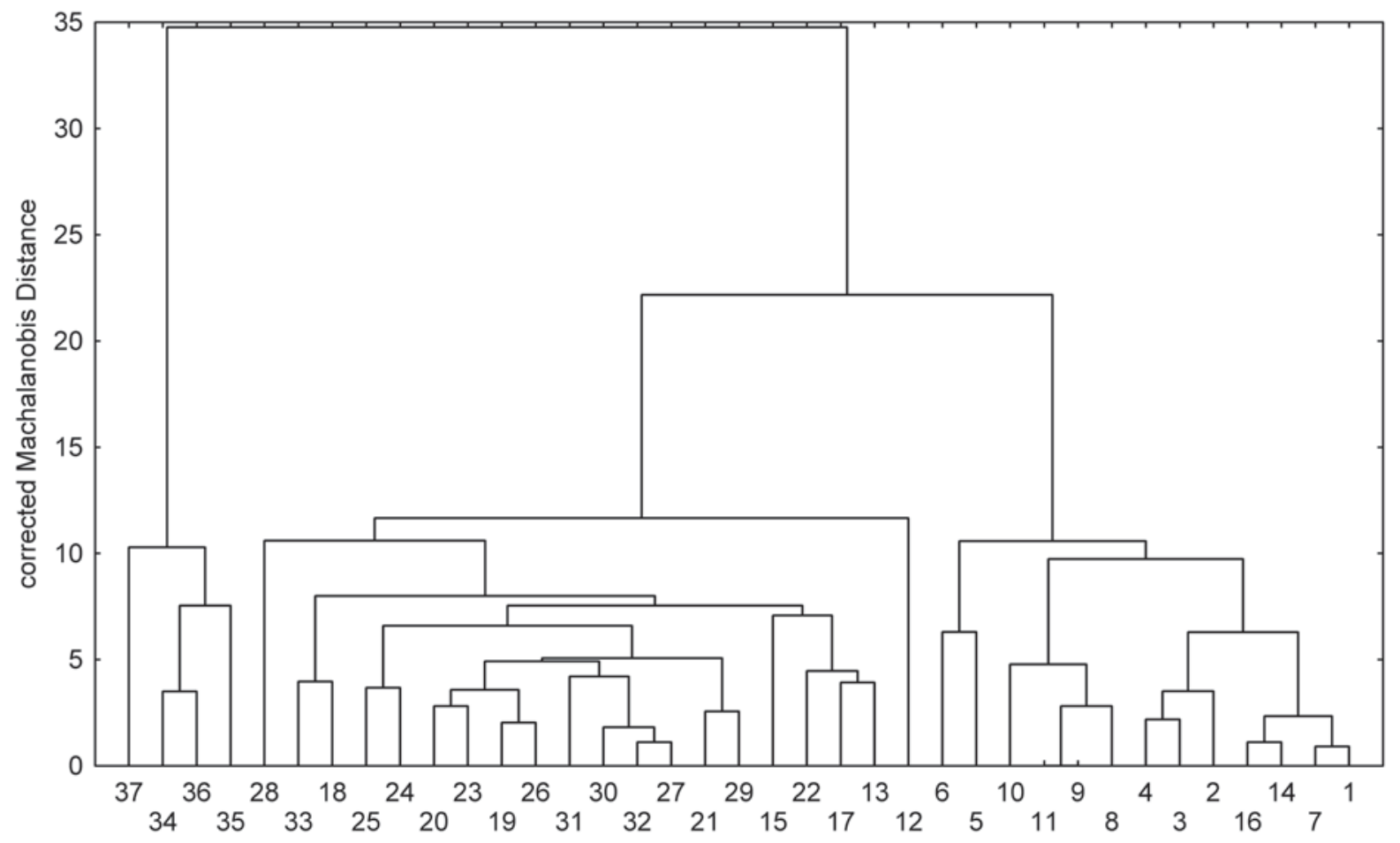

Figure 2. Phenogram of similarity relations between subsamples of Meriones libycus by corrected skull traits resulted from UPGMA cluster analysis. See text for subsample identification.

Table 1. Craniometric characteristics (Limits, Mean \pm Std in $\mathrm{mm}$ ) of three main clusters of Meriones libycus (see text for character abbreviations; rel-BL — relative bullar length, \%).

\begin{tabular}{|l|l|l|l|}
\hline & \multicolumn{1}{|c|}{ African cluster } & \multicolumn{1}{c|}{ "Main Asian" cluster } & \multicolumn{1}{c|}{ SW-N Caspian cluster } \\
\hline ONL & $35.9-42.4,39 \pm 1.39$ & $35.7-45.5,39.2 \pm 1.73$ & $35.2-40.2,38 \pm 1.11$ \\
\hline NL & $13.2-17.1,15 \pm 0.77$ & $13-17.8,15.3 \pm 0.89$ & $13.6-16.5,15.1 \pm 0.64$ \\
\hline NW & $3.2-4.5,3.77 \pm 0.24$ & $3.4-5.1,3.9 \pm 0.27$ & $3.5-4.6,4 \pm 0.23$ \\
\hline IOW & $6.4-8.1,7.1 \pm 0.37$ & $6.3-8.3,7 \pm 0.4$ & $6.1-7.5,6.9 \pm 0.3$ \\
\hline ZW & $19.9-24.1,21.1 \pm 0.79$ & $19-24.4,21.4 \pm 1.07$ & $18.8-23,21 \pm 0.93$ \\
\hline BCW-1 & $20.5-24.3,22 \pm 0.71$ & $19.4-24.7,21.6 \pm 0.91$ & $18.8-22.1,20.5 \pm 0.72$ \\
\hline BCW-2 & $16.1-20,17.7 \pm 0.61$ & $16-19.4,17.4 \pm 0.65$ & $15-17.4,16.3 \pm 0.49$ \\
\hline DL & $8.6-11.2,9.8 \pm 0.52$ & $8-12,9.9 \pm 0.66$ & $9.1-11.1,10.2 \pm 0.43$ \\
\hline IFL & $5.4-8.3,7.1 \pm 0.53$ & $4.9-8.4,6.5 \pm 0.65$ & $5.5-7.4,6.6 \pm 0.38$ \\
\hline TRL & $5-7.6,5.6 \pm 0.34$ & $5.1-8,5.9 \pm 0.37$ & $5.2-6.1,5.7 \pm 0.23$ \\
\hline BL & $15.2-18.2,16.5 \pm 0.59$ & $14.2-18,15.7 \pm 0.66$ & $13.1-15.4,14.3 \pm 0.47$ \\
\hline rel-BL & $39.8-45.4,42.4 \pm 1.1$ & $36.7-43.3,40.0 \pm 1.1$ & $35.8-39.2,37.5 \pm 0.8$ \\
\hline
\end{tabular}

Distribution of specimens in the canonical variables hyperspace (Fig. 3A) indicates that SW-N Caspian cluster takes most isolated position, just as in case of cluster analysis. Other subsamples form continuous distribution with no clear gap between African and "main Asian" clusters. It is to be noticed that the Iranian subsamples previously allocated to the African cluster do actually take intermediate position between the latter and "main Asian" cluster. It is to be noticed also that there are several representatives of the "main Asian" cluster placed quite close to the SW-N Caspian cluster by the first canonical variable values; this indicates that they are similar to the members of the latter cluster in respect to bullar size.

Additional secondary analysis at the specimen level, in which several specimens from the Asian region not allocated to the local subsamples were also included indicate the following (Fig. 3B). The specimens from Arabian Peninsula and Levant take intermediate position between those allocated to African and main Asian clusters. The specimens from Turfan are placed together with those from Middle Asia and Kazakhstan thus showing no evident morphological specificity. 

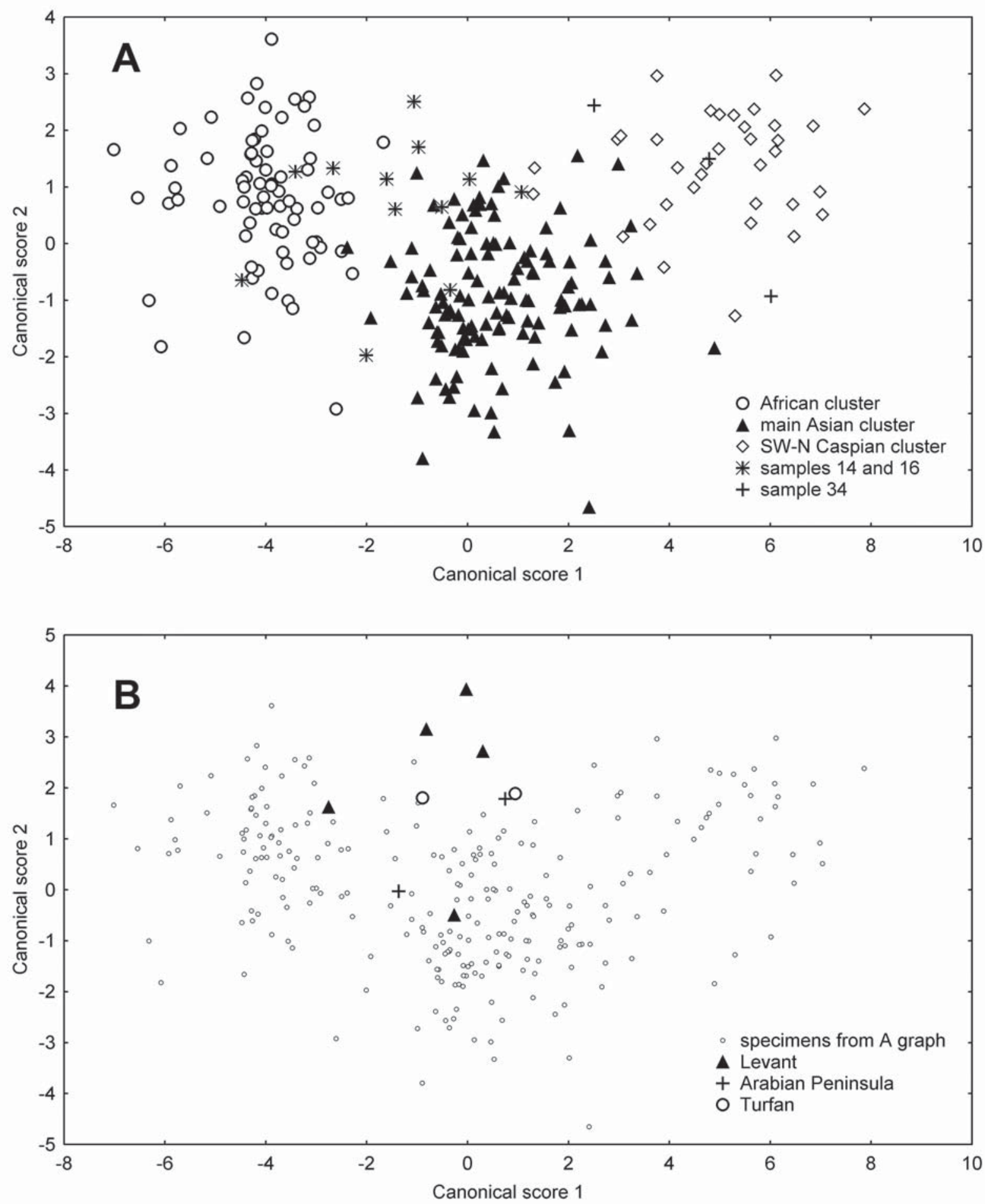

Figure 3. Distribution of specimens in the 1 st and $2 \mathrm{~d}$ canonical variables plane: A - only specimens from main analysis included, B - the specimens from small samples also included.

The principal differences between the three main clusters, after their composition being corrected in accordance with the results of secondary analysis, are as following (Tab. 1). The most expressed are the differ- ences in relative bullar size between SW-N Caspian region and the remainders; the former is characterized by the least auditory bulla, it is largest in the African jirds and somewhat intermediate in those inhabiting 


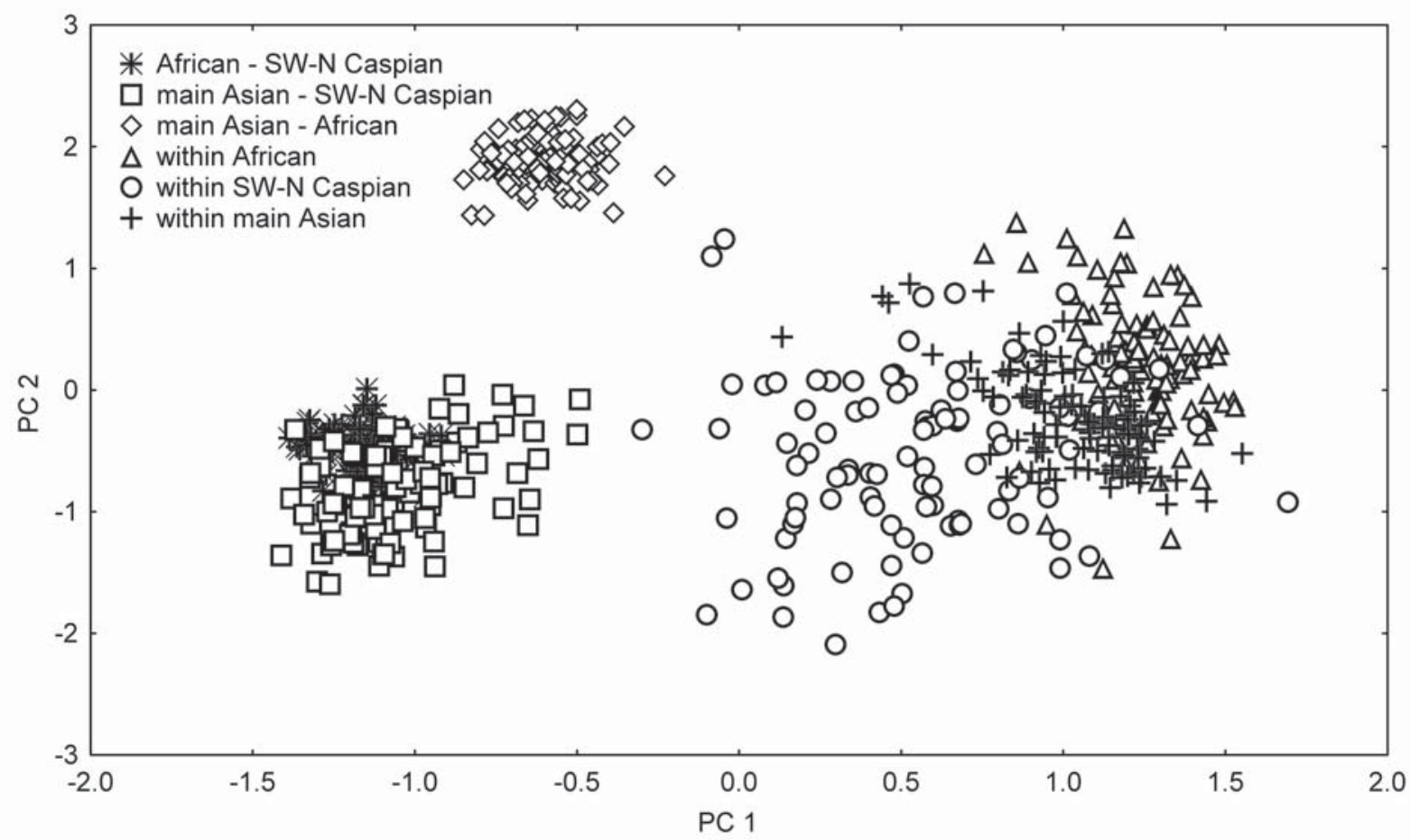

Figure 4. Distribution of eigenvectors of geographic variation within and between main clusters on the plane of the two first principal components of their coordinates.

SW-Middle-Central Asia and Kazakhstan. The principal differences between African and "main Asian" clusters involve incisive foramen length and also bullar length.

Distribution of coordinates of eigenvectors of geographic variation within and between three main clusters indicates the following (Fig. 4). Within-cluster coordinates calculated for each cluster overlap widely, which means quite similar variation pattern in all of them, SW-N Caspian cluster being more specific in this respect. Between-cluster coordinates obtained for pairwise comparisons of these clusters do not overlap with the previous coordinates, which means that between-cluster trends are not the same as within-cluster ones. Besides, of interest is that vector coordinates for Africa and "main Asia" clusters comparison are placed distantly from those obtained for two comparisons in which SW-N Caspian cluster is included. This result could be interpreted as indication that, again, geographic trend within the SW-N Caspian cluster are most specific relative to those observed in both Africa and "main Asia" clusters.

Analysis of bullar variation. Results of linear regression analysis of correlation between relative bullar size and the aridity index indicate the following peculiar features. First, there is a slight negative correlation between the two parameters compared, the Pearson correlation coefficient being equal to $-0.65, p<0.05$. Second, this general trend involves only African and "main Asian" clusters, while SW-N Caspian cluster is characterized by much smaller relative bullar size as anticipated from the values predicted by linear regression (Fig. 5).

\section{Discussion}

The above results clearly indicate that the entire population of the Libyan jird, M. libycus, is divided craniometrically into three main groups differing by both skull proportions and by geographic variation patterns. In both respects, the SW-N Caspian cluster appears to be most distinct, while African and "main Asian" cluster are more similar. The main factor discriminating these groups is relative bullar size, by which SW-N Caspian cluster appears to be most specific in having the least value of this parameter.

Slight negative correlation between bullar size and the aridity observed for the most of the distribution area of the Libyan jird, save SW-N Caspian region, fits general prediction from biomechanical model (Alexander, 1970; Webster \& Webster, 1975). This means that bullar size in this species depends at least in part on the climatic conditions, the jirds inhabiting the most arid deserts having, in average, the largest auditory bulla. But the Libyan jirds inhabiting SW-N Caspian region with its quite arid conditions drop markedly out of this overall trend, so the effects of some other factors cannot be excluded for the latter case.

One of these "other factors" to be taken into consideration could be a historical one. The latter presumes 


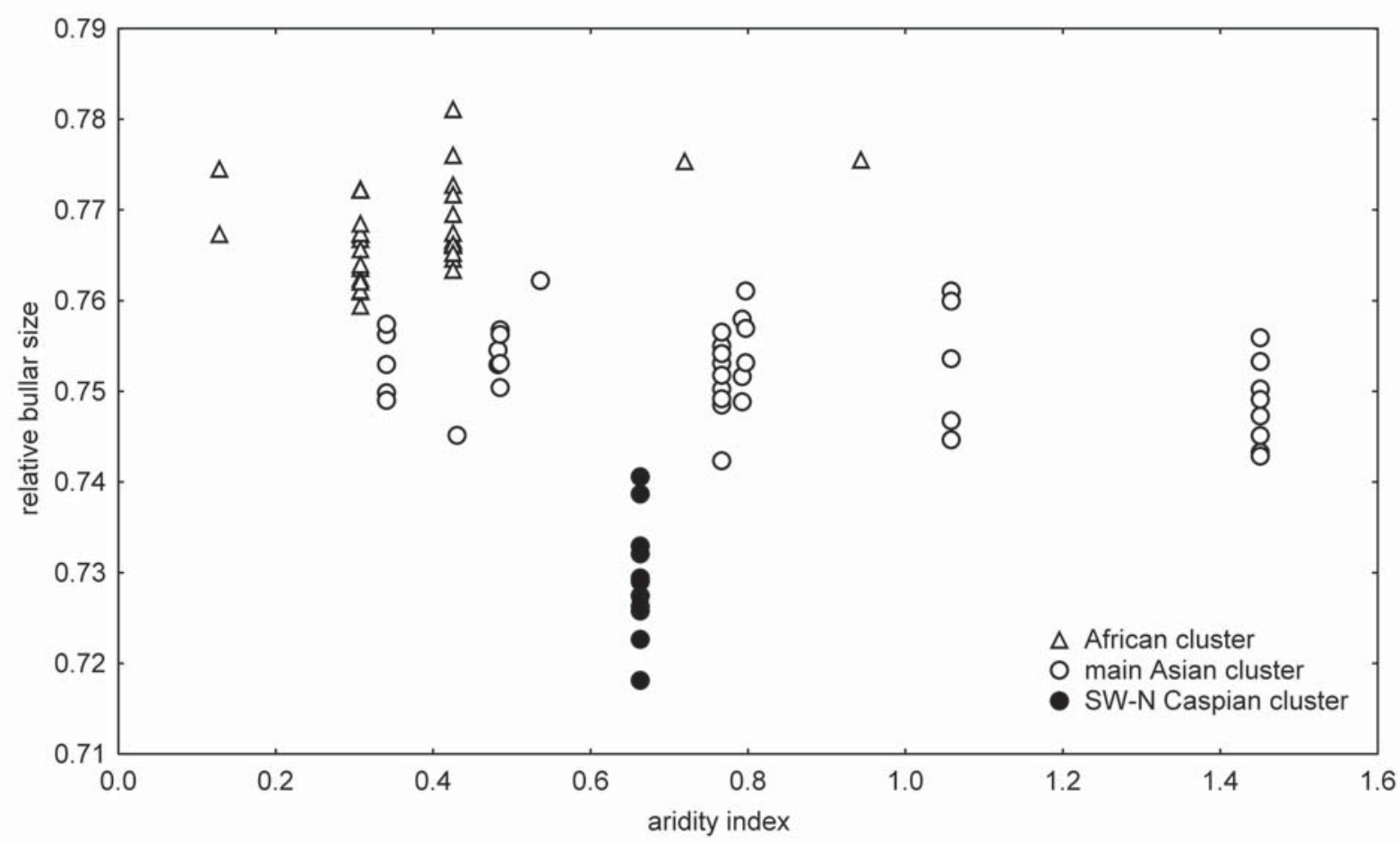

Figure 5. Diagram showing regression of relative bullar size onto aridity index gradient.

that the typical large-bullar Libyan jird had evidently originated from some other Meriones with smaller auditory bulla and that cranial morphology peculiar to the SW-N Caspian cluster could be explained by their preservation of primitive condition. As a matter of fact, it was suggested the Libyan jird had originated from an ancestral form like the Recent small-bullar M. vinogradovi in the west of Iranian Plateau, and spread subsequently over other territories (Heptner, 1940; Pavlinov, 1979; Pavlinov et al., 1990). However, this hypothesis was based on some indirect evidence, in which Pavlinov (op.cit.) included just the small bullar size in the Azerbaijan population, so appealing to it under the present circumstance includes an evident element of circular argumentation.

However, such a historical consideration, whatever true might it be for the Azerbaijan population, is to explain also similarity between the latter and the Emba population. For this, such an explanation is to presume also Libyan jirds migration from Transcaucasia to $\mathrm{N}$ Caspian region along the west Caspian Sea shore. It could occur somewhere in late Pleistocene-early Holocene during Caspian Sea regression when its littoral was free of water and might be covered with steppe biota. The problem is that, at present, the Libyan jirds from Azerbaijan and Emba are separated by far distance of more than $1000 \mathrm{~km}$ of the territories where no population of this species is known to occur. As to the paleontological data, they are quite limited and do not provide any direct evidence for a hypothesis of dispersion of the species under consideration by that rout in the past. Actually, there are several late Pleistocene to Holocene sites at the west side of Volga River delta which contain remains of Rhombomys opimus and several other rodent species known to occur presently in Kazakhstan, but no remains of Meriones of the libycus size were revealed in them (Obolenskii, 1927; Tropin, 1976).

Thus, the causes of small auditory bulla in the Libyan jirds with from SW-N Caspian region remain unclear. More craniometric data from NE (Kazakhstan) and $\mathrm{S}$ (Iran) Caspian regions are requested to study more closely the presumed boundaries between SW-N Caspian and "main Asian" clusters of M. libycus. It's needless to say that special molecular phylogeographic investigation would be of extreme significance in elucidation of distribution history in this species.

Taxonomic implications of our findings might be the following. The previous supposition of quite distinct taxonomic position of population of M. libycus from Transcaucasia is strongly supported thus making M. l. caucasius Brandt, 1855 very "good" subspecies. However, it remains unclear if it is reasonable to unite it taxonomically with population from $\mathrm{N}$ Caspian region to which the name eversmanni Bogdanov, 1889 could be applied. As to the remaining nominal forms of this species, our results indicate clear separateness of African and "main Asian" clusters and uniformity of each of them in respect to craniometric parameters studied by us. Therefore, this could be taken for indication of their low taxonomic significance as far as subspecies differentiation of members of these two clusters is con- 
cerned. The earliest synonym for African forms is libycus Lichtenstein, 1823, and the one for Asian forms (save caucasius-eversmanni) is erythrourus Gray, 1842.

\section{Conclusions}

1. The Libyan jird, M. libycus, is divided craniometrically into three principal clusters: African, SW-N Caspian, and "main Asian" ones. The SW-N Caspian cluster is characterized by the least auditory bulla size. These groups can formally be diagnosable by ratio of bullar and incisive foramina lengths.

2. Auditory bulla size is negatively though not very strongly correlated with the aridity index over the entire species distribution range, but SW-N Caspian form possess much smaller bulla than it is predicted by regression.

3. A hypothesis of historical cause of small bulla in the SW-N Caspian form is considered but it seems to be not strongly supported at present.

4. Subspecies M. l. caucasius from Azerbaijan seems to be most strictly differentiated by cranial morphology. Its taxonomic relation to $M$. l. eversmanni from $\mathrm{N}$ Caspian region needs further clarification. Cranial differences among other nominal forms are insignificant and can be discarder (with certain reservations) in future revisions.

5. The above method of "vector" analysis of geographic trends within large portions of the areas of widely distributed species, such as M. libycus, seems to be useful in providing additional important information concerning biological specificity of respective territorial groupings.

ACKNOWLEDGMENTS. The authors are acknowledged to curators of respective mammal collections, from which cranial materials for M. libycus were studied. Our gratitude is also to Olga Descherevskaya (Moscow) for her having consulted us about meteorological standards.

The study was supported in part by RFBR grant \# 09-04-00283.

\section{References}

Afonin A.N., Greene S.L., Dzyubenko N.I. \& Frolov A.N. 2008. Interactive Agricultural Ecological Atlas of Russia and Neighboring Countries. Economic Plants and their Diseases, Pests and Weeds [Online]. Available at: http:// www.agroatlas.ru.

Alexander R. 1970. [Biomechanics]. Moskva: Izdatel'stvo Mir. 339 p. [in Russian]

Bock W.J. \& Wahlert G. 1965. Adaptation and the formfunction complex // Evolution. Vol.19. No.2. P.269-299.

Borisov A.A. 1977. [USSR. Climate] // Prokhorov A.M. (ed.) [Great Soviet Encyclopedia]. Moskva: Izdatel'stvo Sovetskaya Encyclopedia. Vol.24. Part 2. P.36-42. [in Russian]

Burnaby T.P. 1966. Growth-invariant discriminant functions and generalized distances // Biometrics. Vol.22. P.96110.

Gromov I.M., Gureev A.A., Novikov G.A. et al. 1961. [Mammals of the Fauna of USSR]. Part 1. Moskva-Leningrad: Izdatel'stvo Akademii Nauk SSSR. 638 p. [in Russian]

Heptner W.G. 1940. [The gerbilline fauna of Iran, with zoogeographic peculiarities of Anatolia-Iran-Afghan regions] // Novye Memuary MOIP. Vol.20. P.1-71. [In Russian]

Lay D.M. 1967. A study of the mammals of Iran // Fieldiana Zoology. Vol.54. P. 3-282.

Lissovsky A.A. \& Pavlinov I.Ya. 2008. [Toward exploration of morphological disparity of measurable traits of mammalian skull. 2. Scalar and vector parameters of the forms of group variation] // Zhurnal Obshchei Biologii. Vol.69. No.6. P.344-354 [in Russian, with English summary].

Marcus L.F. 1993. Some aspects of multivariate statistics for morphometrics // Marcus L.F., Bello E. \& García-Valdecasas A. (eds.). Contributions to Morphometrics. Madrid: C.S.I.C. P.95-130.

Obolenskii S.I. 1927. [Rodents of the right bank of Volga River] // Materiali k poznaniyu fauni Nizhnego Povolzhya. No.1. P.1-26 [in Russian].

Pavlinov I.Ya. 1979. [Morphology and taxonomic significance of the middle ear ossicles in the jirds of the genus Meriones (Rodentia: Cricetidae)] // Zoologicheskii Zhurnal. Vol.58. No.11. P.1703-1712 [in Russian, with English summary].

Pavlinov I.Ya. 1979. [On morphology of dental crown of higher gerbillines] // Vestnik zoologii. No.3. P.33-36 [in Russian].

Pavlinov I.Ya. 1982. [Nomenclature and species names in the jirds of the group libycus-erythrourus-shawi-caudatus (Rodentia: Gerbillinae: Merions)] // Zoologicheskii Zhurnal. Vol.61. No.11. P.1766-1768 [in Russian, with English summary].

Pavlinov I.Ya. 2008. [Morphological disparity: General conceptions and basic characteristics] // Zoologicheskie Issledovaniya. Sbornik trudov Zoologicheskogo muzeya MGU. Vol.49. P. 343-388 [in Russian, with English summary].

Pavlinov I.Ya., Dubrovsky Yu.A., Rossolimo O.L. \& Potapova E.G. 1990. [Gerbillines of the World Fauna]. Moskva: Izdatel'stvo Nauka. 308 p. [in Russian]

Ranck G.L. 1968. The rodents of Libya: Taxonomy, ecology and zoogeographical relationships // Bulletin of U.S. National Museum of Natural History. No.275. P.1-264.

Setzer H.W. 1961. The jirds (Mammalia, Rodentia) of Egypt // Journal of Egyptian Public Health Association. Vol.36. No.1. P.81-92.

StatSoft Inc. 2007. STATISTICA (data analysis software system), version 8.0. ww.statsoft.com.

Tropin N.N. 1976. [Changes in the Late Quaternary mammal complexes and rodent faunas of the southern part of Volga-Ural interfluve] // Trudy Zoologicheskogo instituta AN SSSR. Vol.66. P.125-131 [in Russian].

Webster D.B. \& Webster M. 1975. Auditory systems of Heteromyidae: functional morphology and evolution of the middle ear // Journal of Morphology. Vol.146. No.2. P.343-376. 